\title{
Foreign Cultural Policy: The Lack and Importance of Public Diplomacy in Israel's Public Image Restoration
}

\section{Nadyara Nafisa}

Mahasiswa Jurusan Hubungan Internasional, Fakultas IImu Sosial dan IImu Politik, Universitas Katolik Parahyangan

\begin{abstract}
Abstrak
Eksistensi Israel sebagai sebuah entitas negara kerap mengalami berbagai pergolakan sejak kemerdekaanya pada 14 Maret 1947 silam. Berbagai polemik yang mengancam kedaulatan- secara spesifik keutuhan wilayah geografisnya serta konflik panjang yang dihadapinya dengan Palestina telah menjadi bagian dari prioritas kepentingan nasional yang melahirkan sintesa kebijakan luar negeri yang berorientasi sektor pertahanan dan militer memberikan implikasi pada pemusatan aplikasi konsepsi hard power. Simpati masyarakat internasional terhadap Palestina, korban jiwa yang berjatuhan, dan pemberitaan media internasional terhadap Israel telah memberikan beban baru bagi tubuh Israel sendiri: citra negara yang buruk dengan diskursi yang berkembang dalam masyarakat internasional berupa "penolakan" Israel atas perdamaian dunia melalui kebijakan militer bersakala besar yang memakan banyaknya korban jiwa. Pada saat yang sama, dunia internasional tengah dihadapkan pada era globalisasi, dimana hal ini turut mempengaruhi bentuk diplomasi sebagai instrumen kebijakan negara dengan mengedepankan konsepsi citizen and cultural oriented yang kemudian dikenal sebagai diplomasi publik selain instrumen hard power dalam memperjuangkan kepentingannya. Dalam paper ini, penulis akan membahas pentingnya diplomasi publik sebagai instrumen kebijakan luar negeri Israel yang berbasis budaya dalam membangun kembali citra negaranya dan upaya yang telah dilakukan pemerintah Israel terkait dengan diplomasi publik. Untuk melengkapi pemahaman dalam topik pembahasan paper ini, penulis turut menyertakan perspektif foreign cultural policy dan diplomasi publik. Sebagai konsensus dari pembahasan, penulis berargumen bahwa diperlukan adanya atensi lebih terhadap pentingnya diplomasi publik sebagai instrumen penting dalam upaya membangun citra baru Israel.
\end{abstract}

Keywords : Public Image, Image Restoration, Public Diplomacy, Culture, Foreign Culture Diplomacy

\section{Introduction: Israel and Its Current Public Image}

During the years of Israel's existence since its independence as a nation state in 1948, Israel has always struggled to maintain its positive reputation in international 
society. Its public image remained quite positive from the period of Arabs- Israeli peacemaking process including the Oslo negotiation forum (1993-1994) which later produced Oslo Accord. The Israel goverment had agreed on the withdrawal of its military and administrative settlement on West Bank and Gaza Strip and thus giving the Palestinian Authority (PA) the legitimation to run Palestine's first democratic election on 1996. On the contrary to it, Israel has always lived in the shadow of Hammas' terror attacks. ${ }^{1}$ A negotiation should have mutual gains for parties involved and regarding to this, Israel Security Official had long warned the PA that Israel couldn't continue to implement the agreement on the negotiation if PA had been kept on giving Hamas authority and freedom to do a terror attack as there is a sense of unfairness in the implementation. ${ }^{2}$ As the respond, Yasser Arafat kept on doing several negotiations with Israel's former foreign minister Peres like nothing actually happened. ${ }^{3}$ Back then in 1991, Israel has gained international sympathy for its decission to discontinue their strikes on Iraqi missile attacks in its major cities.

However, things have changed since the outbreak of Arafat's "Al Aqsa Intifada" or the Israel- Palestinian war on 2000 -- the second biggest after the 1948 war. Israel's self-defense actions on the uprising Palestinians against Israel's setllement on West Bank and Gaza Strip has always been on the media's spotlight. Every military self-defense means commited by the IDF soldiers often killed a large number of Palestinians inlcuding children, youths, and civilians as the part of noncombatans. It's noted that over six years of first intifada, the IDF killed an estimated 1,162-1,204 civilians. $^{4}$ Since then, Israel has always been subjected to many violations of human rights. Its reputation abroad has dramatically deteoriated. Israel

\footnotetext{
${ }^{1}$ John Guigley, The Six Days of War and Israel Self Defense: Questioning the Legal Basis for Preventive War, Cambridge University Press: 2012, h.67

${ }^{2}$ Quandi, B. Williams, "Israel-Palestinians Peace Talks", dalam How Israeli and

Palestinians Negotiate, Washington DC: US Institute of Peace Process, 2006, h. 200

${ }^{3}$ Ibid., h.208

${ }^{4}$ Rami Nasrallah, "The First and Secod Palestinian Intifadas" in Joel Peters, David Newman, "The Routledge Handbook on The Israeli-Palestinian Conflict", Routledge: 2013, h.61
} 
has become a state whose existence and its capital, Yerussalem, is being questioned and unrecognized by several states. Israel leaders and its policies are often compared with Nazi Germany. ${ }^{5}$ Hence, Israel's actions to Palestina are often compared to the apartheid condition in South Africa. ${ }^{6}$ All of these comparisons are aimed to desolate, de-legitimaze, and destroy the reputation of Israel. The international response including United Nations doesn't seem to help. Along with the responses from several International NGOs such as ICRC, Human Rights Watch, and Amnesty International, Israel's actions and policies has been frequently critized while serious human rights violations on the part of Arab and Palestinians done by Hammas and PLO have always been ignored. ${ }^{7}$ Having bad reputation as human rights violator, many states and international organiations have boycotted trade and academic relations with Israel and also issue some divestment campaigns.

Media coverage plays a "two swords" and bias role on portraying Israel's public image. The portrayal made on Israel's public image and the framing medias give in the issues related to Israel - specifically on the conflict of Israel-Palestina has been really depending on which side that the medias support. Some medias would stress the coverage on actions done by Hammas in West Bank and Gaza Strips-but most of them would stress the coverage on actions done by IDF (Israel Defense Force). This make news spreading on medias related to the conflict mostly become wrapped in biases. The disproportionate attention by medias devoted to the conflict later often produce stories and news which are driven more by ideological consideration rather than the journalistic ethic ones. ${ }^{8}$ By these, Israel and its long

\footnotetext{
${ }^{5}$ Ibid., h.300

${ }^{6}$ William Booth, "The Israeli General who Compared the Jewish State to Nazi-era Germany", The Washington Post, http://www.thewashingtonpost.com/amphtml/news/worldviews/wp/2016/05/08/the-israeligeneral-who-compared-the-jewish-state-to-Nazi-era-Germany, diakses pada 9 April 2017 7 "Comparing South African Apartheid to Israeli Apartheid", It Apartheid.org: Get Informed, http://www. itsapartheid.org>Documents_pdf_etc, diakses pada 4 April 2017 ${ }^{8}$ Matii Friedman, "What the Media Gets Wrong About Israel", The Atlantic Daily, http://www.theatlantic.com/amp/article/383262, diakses pada 16 April 2017
} 
fight for their teritorial integrity have lived with its reputation as the example of gross " moral failure" and also the violator of human rights by international law.

\section{Public Diplomacy as Foreign Cultural Policy's Tool}

The term " foreign policy" has been defined in many ways. Padelford and Lincoln defined foreign policy as "the key element in the process by whih a state translates its broadly conceived goals and interests into concrete courses of actions to attain these objectives and pressure its interests." 9 C.C. Rodee, in other way, defined the term as "formulation and implementation of a group of principles which shape the behaviour pattern of a state while negotiating with (contacting) other states to protect or further its vital interest". ${ }^{10}$ Josep Frankel explained the term "consist of decissions and actions which involve to some appreciable extent relations between one state and others." ${ }^{11}$ By these definitions, we could conclude that foreign policy is a set of formal and official actions by goverment to achieve state's goals and national interests.

Foreign policy is aimed to reach state's national interest by using its tools such as diplomacy, foreign aid, and military force. The term foreign cultural diplomacy itself stresses on policy which intended to promote state's culture abroad or using state's culture to reach its national interests. The tools used on foreign cultural policy is public diplomacy. To this day, there haven't been any one exact definition on public diplomacy itself. According to Nicholas J Cull from USC Center on Public Diplomacy, in line with the definition from Dictionary of International Terms published by United States, public diplomacy or "citizen diplomacy" is a programme sponsored by goverment in order to influence state's public opinion abroad; its instruments including publications, animations, cultural exchange, radio, and

\footnotetext{
${ }^{9}$ Norman J. Padelford dan George A. Lincoln, The Dynamics of International Relations, Macmillan: 1962, h.197

${ }^{10}$ C.C. Rodee, Introduction to The Foreign Policies of the Power Political Science, h.571

${ }^{11}$ Joseph Frankel, The Making of Foreign Policy, London Oxford University Press:1988, h.1 
television. ${ }^{12}$ Pursuant to Alan K. Henrikson, a professor on History of Diplomacy, public diplomacy is a form of international relations by goverment through public communication media and its process is facing many non-state entities in its mean to influence other state's politics and actions. ${ }^{13}$

The evolvement of public diplomacy has grown along with the development of technology, communication, and also globalization. People has become more connected from one state to others (interconnectedness) which also supported by the development of telecommunication media and thus makes the flow of information has become easier to get. In this case, goverment have started to realize the ineffectivenes of first track diplomacy (by goverment) which tend to be rigid and unreachable to society. Therefore, with the increasing level of interconnectivity in society and also the flow of information from people in one state to others, their participation in the form of public opinion is used as the main element in public diplomacy where diplomacy is done in order to influence people by using telecommunication media as its vital instrument. Several aims pursued in public diplomacy are to influence other's state actions, to give information, as well to strengthen state's soft power by giving information related to culture and lifestyle in the state concerned. It also helps to create a greater and mutual understanding between states involved within each citizens.

As the name suggests, public diplomacy or citizen diplomacy involves people or other non-state actors as the proponent of the effort done by the goverment as the first track to subdue their limitation. However, the term of first and second tracks diplomacy ( non-state actors) cannot longer explain the global condition of international society which has been more aware of the importance on world peace. ${ }^{14}$

\footnotetext{
12 “What is Public Diplomacy?", USC Center on Public Diplomacy, diakses pada 13 April 2017, http://www.uscpublicdiplomacy.org/page/what-pd

${ }^{13}$ Ibid.

${ }^{14}$ Sukawarsini Djelantik, Diplomasi: Antara Teori dan Praktik, Yogyakarta: Graha Ilmu, 2008, h. 74
} 
Later, this thought brings out the concept of multitrack diplomacy which introduced by Louise Diamond and John McDonald to explain the other nine tracks which aim to support the first track ( goverment) in their effort. The nine tracks above is explained as the picture below:

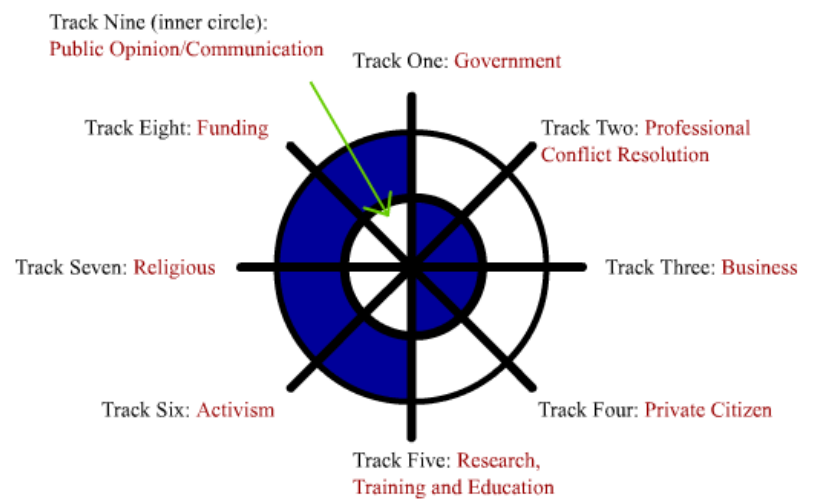

Picture 1: Multitrack Diplomacy. Source: www.uscpublicdiplomacy.co

\section{The Importance of Public Diplomacy in Israel's Public Image Restoration :} Lack of Goverment Support and Pragmatic Approach on Foreign Policy

As stated before, by every media coverages on Israel's persistent effort to defend its integrity and sovereignity, the state has always struggled to maintain its positive public image abroad. Other than military means as the traditional way to preserve the state's security and firm relations with other countries, public diplomacy could also be the first option in this globalized and multi actors era. Public diplomacy is using a bottom-up approach by involving the citizens and creating a mutual; friendly relations and understanding between the states involved. Later, it could help to lessen or prevent the appearance of conflict between states and thus help to encourage citizens voice. Public diplomacy or "citizen diplomacy" itself is defined as a programme sponsored by goverment in order to influence state's public opinion 
abroad. ${ }^{15}$ Currently, Israel's cultural efforts are organized by the The Minister of Education, Culture, and Sports in Jerusalem. There are also The Culture and Arts Administration (CAA), National Council for Culture and Ats, and te Council of Museums and the Council of Public Libraries below the administration of the Ministry. There are also several governmental organizations or agents help on promoting Israel's culture such as The Israel Antiquities Authority, The Israel Music Institute helps on promoting Israel's music and The Institute for the Translation of Hebrwe Literature, and Jewish National and University Library. Israel's IDF itself has its military museums administered by the Ministry of Defense. Lately, each of cities in Israel has their own cultural department specifically at some of big cities including Yerusalem, Tel Aviv, and Haifa. Most of the organizations and cultural department are funded by CAA. ${ }^{16}$

Although the Israel has already had their strong capacity needed to build its "new" reputation ahead through the strong and structurized governance body to help promote cultural programme, the problem arised because most of the organizations and departments focus mainly on the development of culture within inside the Israel without having any abroad orientation. According to Jackie Eldan, Head of Bureau and Senior Deputy Director General of Israels Ministry of Foreign Affairs, the Goverment of Israel doesn't really recognized the importance of public diplomacy withn a note that the govermental budget allocated to the Ministry of Foreign Affairs on public diplomacy has been really modest-13,7 million shekels which marked fifteen percent of the general activities budget of the Ministry of Foreign Affairs. ${ }^{17}$ However, many cultural organizations and agencies in Israel has expressed its frustation over goverment budget allocated to promote any future development of

\footnotetext{
${ }^{15}$ USC Center of Public Diplomacy, Ibid.

${ }^{16}$ Israeli Arts Directory, "Cultural Policy and Infrastructure," http://www.culture.org/il/directory/cultralpolicy.asp, diakses pada 16 April 2017

${ }^{17}$ Press Release: State of Israel Ministry of Science, Culture, and Sport, Spokeperson's Office, http"//www.most.gov.il/.../0/2007 , diakses pada 15 April 2017
} 
arts and design mainly for international purpose. According to the goverments budget on cultural programme in 2015, the budget given is up to 293 million shekel which doesn't abide the UNESCO declaration adopted by Israel in which states that the country's budget for culture must not less than one percent of the entire goverment budget. $^{18}$

Israel's lack of attention on cultural diplomacy can be seen on its lack of funding in the state's cultural programme intended for international purpose. The state's $60^{\text {th }}$ anniversary celebration is the best example given to this case. This event was first intended to be held abroad in other states by the purpose on promoting Israel's culture, creating a more positive outlook on the state's public image, and also maintaining a friendly relation between the states and their citizens. The Art Department of the Ministry of Foreign Affairs was planned to get one hundred million shekels for the event but there have been no budget allocated despite their constant effort pull by the Ministry to get the funding. ${ }^{19}$ Moreover, the Goverment felt that the funding was better to spend on domestic events. ${ }^{20}$ Due to these obstacles, the programme was finally cancelled.

The program cancellation and lack of funding have created a degree of discomfort between Israel and other countries. It can be seen as Israel Culinary Week in Uruguay and the "Israeli Season" program in Poland were cancelled and reduced. ${ }^{21}$ Germany has been one of the countries which has specifically maintained their effort in helping Israel's cultural diplomacy by hosting extensive events related to Israel's culture in Berlin. The state expressed its dissapoinment over Israel's minimal contribution in the event's funding and also the cancellation. Thus, the dissapoinment

\footnotetext{
${ }^{18}$ E Gilboa, "Public Diplomacy: The Missing Component in Israel's Foreign Policy", Israel Affairs, http://www.beta-iatefl.hit.bg/pdfs/case_study.pdf., diakses pada 15 April 2017

${ }^{19}$ Bronfman R. C, “ YEC Needs Communal Funds", Haaretz.com, from www.haaretz.com/hasen/spages/914143.html , acessed on April 25th 2017

${ }^{20}$ Tzipi Shochat, כל תכני הארץ בכל מכשיר ובכל זמ, Haaretz.com, http://www.haaretz.co.il/gallery/1.1314772, Acessed on April 25 2017

${ }^{21}$ Ibid.
} 
later get into the Israel's goverment attitude toward Youth Exhange Comission (YEC). The student exchange program is aimed to bring the bridge between Germany and Israel after the Holocaust by creating a mutual understanding between the youth of two states. Regarding to this, Israel has shown a very minimal effort on YEC's funding. the German government helps fund the costs of the visit, with no assistance from the Government of Israel.

Rather than improving its positive public image abroad, Israel has only created more and more tensions abroad by its insufficient effort made on public diplomacy and international culture promotion programme. On a state where its integrity and public image has been continously challenged, putting any efforts on public diplomacy to help strenghten the state's positive image abroad is important as it could also help minimizing the tension, conflict, and missunderstanding which often appointed on Israel. On a survey conducted by The Anholt Nations Brand Index (NBI), an index measure the public image or nation branding of many states in the world made by Simon Anholt, Israel has itself as the worst brand name in the world on 2006 and haven't changed later until the latest poll held on $2016 .{ }^{22}$ Responding to this, Anholt said that, "Israel's brand is by a considerable margin the most negative we have ever measure in the NBI, and comes bottom of the ranking on almost every question." 23

However, the negleted status of public diplomacy as Israel's public image restoration means must also be seen from the other perspective, such as the status quo of its constantly challenged teritorial integrity which the state has been facing since the day of its establishment. As the result of its existential threat, the state has always

\footnotetext{
${ }^{22}$ Simon Anholt, "Global Survey Confirms Israel is the worst Brand in the World", Nation Brand Index, Accessed on April, $21^{\text {st }} 2017$ www.nationbrandindex.com/nbi_q306-usa-pressrelease.phtml.

23 "Survey: Israel Worst Brand Name in the World", Israel Today, http://www.israeltoday.co.il/default.aspx?tabid=178\&nid=10395, Accessed on April 25th, 2017
} 
focussed and shaped itself on military efforts. On the time when the situation is more peaceful, the Ministry of Foreign Affairs has received a bigger fnding on public diplomacy. However, the state has always prefer to allocate the budget to the Ministry of Defense specially in the difficult times. ${ }^{24}$ This pragmatic and direct approach has also been shaped by the decission maker behind it. Most of the states' top political positions have always been filled with the ones with military and intelligence forces background (IDF and Mossad). To the example from it, most of Israels prime minister are those with top position on IDF such as Benjamin Netanyahu, David Ben Gurion, and Rabin. The nature of the public diplomacy itself tend to be intangible, time-consuming with a long time investment, and intangible benefits which make the state which facing the continously existential threat everyday prefer such a pragmatic military means, short, and direct foreign policy. Despite everything, Amir Ofek from the Ministry of Foreign Affairs said that, "One has to convince people that culture is important. Some feel that it is more important to focus on political content and not culture because, as they see it, culture won't change people's minds about the political situation in Israel." 25

The minimum role of public diplomacy in Israel as the public image restoration tool can also be explained in the concept of "Gun and Butter" which was first introduced William Jennings Bryan, the United States Secretary of State during the Wilson Administration. It is described that the state will have to decide between the "the guns" ( the defense budget) and "the butter" (the needs of the citizens) as both couldn't balance each other and go together with its choice being partly influenced by the military spending and military stance of potential opponents. ${ }^{26}$ Any

\footnotetext{
24 "Israel Defence Spending", The Economist, http://www.economist.com/news/middle-eastand-africa/21660998-generals-blow-away-plan-cut-their-budgets-locker-hurt, accessed on April $25^{\text {th }}, 2017$

${ }^{25}$ Israel Today, Ibid.

26 "Gun and Butter", The Truth About Money and Goverment, http://politicaleconomy.com/guns-or-butter/

Accesed on April, 30th , 2017
}

FOREIGN POLICY 
of the choice prefered has its own benefit and consequence as the choice on the guns also has its consequence on the unfulfillment of the citizens welfare. Israel has become the state which always prefer the gun over the butter by the nature of its existential threat. This has costed in the maximum concern on the military means, the lack of attention given to the diplomatic courses, death of its own civillians and also the death of peace. Thus, this concept explains why any diplomatic means including public diplomacy in Israel become neglected as the state preference to the guns couldn't guarantee the outgoing progress of the butter.

\section{Conclusion}

On a country where survival, existential threat, and bad media coverage have become the daily doses of main concerns, Israel has always been in a complex position which unfortnately also place the state in a negative public image abroad. Its military means as the way to preserve its teritorial integrity has always got any negative media coverages as the violator of international law and human rights. However, in this globalized era where citizens could also be the agent of diplomacy in the hope of achieving the world peace, public diplomacy is neverthlessly important to Israel as the effort of image restoration by creating a mutual understanding between the citizens through the cultures spreading through media and done by the goverment. However, this still can't maximally be implemented as the state is still putting its main focuss on military means - a mere pragmatic approach due to the threat Israel faces everyday so that the goverment itself doesn't pay its attention on the funding allocated to the programme related to public diplomacy. One should be conviced that by pulling the time-investing effort on public diplomacy, Israel could reduce the existing conflicts and thus help gaining mutual understanding between the states through the involvement of the culture, media, and citizens. 


\section{Bibliography}

\section{Books}

Djelantik, Sukawarsini. Diplomasi: Antara Teori dan Praktik.Yogyakarta: Graha Ilmu. 2008.

Frankel, Joseph. The Making of Foreign Policy. London Oxford University Press:1988.

Rodee, C.C. Introduction to The Foreign Policies of the Power Political Science.

Guigley, John. The Six Days of War and Israel Self Defense: Questioning the Legal Basis for Preventive War.Cambridge University Press: 2012

J. Padelford, Norman dan George A. Lincoln. The Dynamics of International Relations. Macmillan: 1962

Williams, B. Quandi. "Israel-Palestinians Peace Talks" dalam How Israeli and Palestinians Negotiate. Washington DC: US Institute of Peace Process, 2006

\section{Journals}

Gilboa, E. "Public Diplomacy: The Missing Component in Israel's Foreign Policy". Israel Affairs, http://www.beta-iatefl.hit.bg/pdfs/case_study.pdf.

Nasrallah, Rami. "The First and Secod Palestinian Intifadas" in Joel Peters and David Newman. "The Routledge Handbook on The Israeli-Palestinian Conflict". Routledge: 2013.

\section{Internet}

Anholt, Simon. "Global Survey Confirms Israel is the worst Brand in the World".Nation Brand Index, www.nationbrandindex.com/nbi_q306-usa-press-release.phtml.

Booth, William. "The Israeli General who Compared the Jewish State to Nazi-era Germany". The Washington Post. http://www.thewashingtonpost.com/amphtml/news/worldviews/wp/2016/05/08/theisraeli-general-who-compared-the-jewish-state-to-Nazi-era-Germany.

"Comparing South African Apartheid to Israeli Apartheid". It Apartheid.org: Get Informed. http://www. itsapartheid.org>Documents_pdf_etc.

Friedman, Matti. "What the Media Gets Wrong About Israel". The Atlantic Daily.http://www.theatlantic.com/amp/article/383262.

"Gun and Butter". The Truth About Money and Goverment. http://politicaleconomy.com/guns-or-butter/

Israeli Arts Directory. "Cultural Policy and Infrastructure," http://www.culture.org/il/directory/cultralpolicy.asp 
"Israel Defence Spending". The Economist. http://www.economist.com/news/middle-eastand-africa/21660998-generals-blow-away-plan-cut-their-budgets-locker-hurt

Press Release: State of Israel Ministry of Science, Culture, and Sport. Spokeperson's Office. http"//www.most.gov.il/.../0/2007

R,C., Bronfman. “YEC Needs Communal Funds”. Haaretz.com, from www.haaretz.com/hasen/spages/914143.html

Shochat, Tzipi. כל תכני הארץ בכל מכשיר ובכל זמ. http://www.haaretz.co.il/gallery/1.1314772.

"Survey: Israel Worst Brand Name in the World". Israel Today. http://www.israeltoday.co.il/default.aspx?tabid=178\&nid=10395

“What is Public Diplomacy?”. USC Center on Public Diplomacy. http://www.uscpublicdiplomacy.org/page/what-pd 